\title{
The influence of fungicides and growth media on the morphological and physio- biochemical parameters of Citrus rootstocks
}

\author{
Asad Abbas ${ }^{1}$, Asif Zulfiqar², Muhammad Irfan Ahmad ${ }^{3}$, Muhammad Arsalan Tahir ${ }^{4}$, Adnan Noor Shah ${ }^{*}$ \\ ${ }^{1}$ School of Horticulture, Anhui Agricultural University, Hefei, 230036, China \\ ${ }^{2}$ Department of Horticulture, Faculty of Agriculture University of Sargodha Pakistan \\ ${ }^{3}$ School of Agronomy, Anhui Agricultural University, Hefei 230036, China \\ ${ }^{4}$ Department of Plant Pathology, Faculty of Agriculture University of Sargodha Pakistan \\ ${ }^{5}$ Department of Agricultural Engineering, Khwaja Fareed University of Engineering and Information \\ Technology, Rahim Yar Khan 64200, Pakistan \\ Corresponding Author*: ans.786@yahoo.com
}

\begin{abstract}
The current study was designed to monitor the effects of standardized grown media and fungicide on citrus rootstock propagation. For this purpose, two fungicides and four different commercially available sterilized growing media were used to study Citrus morphology and physicochemical parameters. The four different rootstocks of citrus Carrizo citrange (Citrus sinensis L. Osb. × Poncirustrifoliate L.), Cleopatra mandarin (Citrus reticulate Blanco), Rough lemon (Citrus jambhiri L.), Sour orange (Citrus aurantium L.) while two fungicides' Aliette' (Fosetyl Aluminium 80\% Nonylphenol ethoxylate 6.18\% Ligno sulfonic acid, sodium salt, sulfomethylated $4.40 \%$ Crystalline quartz) and 'RidomilGold' (Mefenoxam 45.3\%) with four different commercially available sterilized growing media (peat moss, vermicompost, sawdust, fine sand) were used. Results showed the most significant increase in morphology and physiology of Cleopatra mandarin rootstock treated with fungicide Aliette (FosetylAluminium) grown in peat moss. It was observed that the fresh, dry biomass, shoot length, root length, fresh biomass, dry biomass, number of leaves, photosynthesis rate, transpiration rate, stomatal conductance, water use efficiency, and chlorophyll contents increases as compared to other treatments and other citrus rootstocks. It may be concluded that the fungicides have an impact on citrus growth and the developmental process.
\end{abstract}

Keywords; Fungicides, growth media, rootstocks, morphological and physiochemical characters.

\section{Highlight:}

- Morphological changes of citrus rootstock under various fungicides and growing media.

- Physio-biochemical characterization of citrus rootstocks responds to differentially used fungicides like (Fosetyl Aluminium, Mefenoxam) and growing media (peat moss, vermicompost, sawdust, fine sand).

- Assessment of best-combined media to promote growth and development of citrus rootstock.

\section{INTRODUCTION}

Citrus is one of the major fruit crops of the world due to its popularity and availability to human diets belongs to the family Rutaceae, native to Southeast Asia and now widely grown worldwide. Initially, it was brought to North Africa and entered Europe with the collapse of the Roman Empire. Then it was brought to America by Spaniards. Citrus is an abundant source of vitamin C, Sugar, and minerals like Calcium (Ca) and Magnesium (Mg). It prevents cancer of the lungs, liver, and skin and helps prevent heart disease and congenital disabilities (Cirmi, et al., 2017; KlimekSzczykutowicz et al., 2020). Citrus fruits are grown in tropical and sub-tropical regions of $35^{\circ} \mathrm{N}$ and $35^{\circ} \mathrm{S}$ latitude in the northern hemisphere of more than 140 countries. Pakistan is in the $13^{\text {th }}$ position among Citrus growing countries of the world. Citrus occupies the first rank concerning area and production among all fruits. The global average production of Citrus is 1760.3 thousand tons on an area of 176.5 thousand/ha. Punjab shares $94 \%$ and $96 \%$ in size and production, respectively. Based on genomic, phylogenetic, and biogeographic analyzes of 60 different citrus and associated accessions, it has been suggested that the origin center of citrus species was the southeastern foothills of the Himalayas, in a region that encompasses the southern area of Assam, southern Myanmar, and southern Yunnan (Wu, et al. 2018).

Pakistani citrus crops are subjected to several biotic and abiotic factors; drought is the most evident one. Reduces gas exchange and photosynthesis rates are the consequences of drought stress. It is a type of dehydration that happens when water is scarce and moisture losses occur due to excessive transpiration (Hussain, et al., 2018; Riaz, et al., 2013). Because of certain fungi, nematodes, drought, and salinity, citrus cultivars face problems, and a significant reduction in production becomes uneconomical in several countries of the world. Citrus is now universally propagated to overcome such issues by budding and grafting onto rootstocks. By choosing suitable rootstocks, the devastating effects of these factors can be controlled (Ribeiro, et al., 2014). Rootstocks are susceptible to particular circumstances such as illnesses, 
salinity, and acidity. They have an impact on nutrient supply, quality, and size of scion fruit. There is no ideal citrus rootstock; even Rough lemon is susceptible to frost. Brazilian Sour Orange is regarded as well-adapted to alkaline and saline soils in Texas, USA. Rough lemon has drought-tolerant characteristics.(Ribeiro, et al., 2014; Zaher-Ara, et al., 2016). Early categorized citrus species were used in three groups as rootstocks: Citrus reshni (Cleopatra mandarin) as excellent salt-tolerant, Citrus volkameriana (Volkamer lemon) and Citrus aurantium (Sour orange) as medium salttolerant, and Poncirus trifoliata (Trifoliate orange) as bad salt-tolerant (Fadli, et al., 2015). Rootstock and scion are two significant parts of citrus trees. Compatible rootstock and scion combination make the plant more productive with excellent fruit quality (Ribeiro, et al., 2014). Rootstock-scion incompatibility is a severe issue in all citrus-growing countries, and researches have been carried to overcome this problem (Albacete, et al., 2015). In Punjab province (Pakistan), the rootstock, which shows the best performance at one time, may not show the same performance in the future due to severe problems involved in citrus decline (Hussain, et al., 2018; Riaz, et al., 2013). Growers use rootstocks as a tool to manipulate the efficiency and vigor of the orchard. Rootstock affects tree size, precocity, maturity (Fallahi, et al., 2001).

Carrizo citrange is mainly used as a rootstock in Citrus due to its resistance to Citrus tristeza virus and Phytophthora species and the high-quality yield of the fruit that gives the scion. The genetic manipulation of this rootstock can alter the scion's growth and promote various cultural activities (Wu, et al., 2018). The genealogy of citrus rootstocks is shown in Figure. 1.

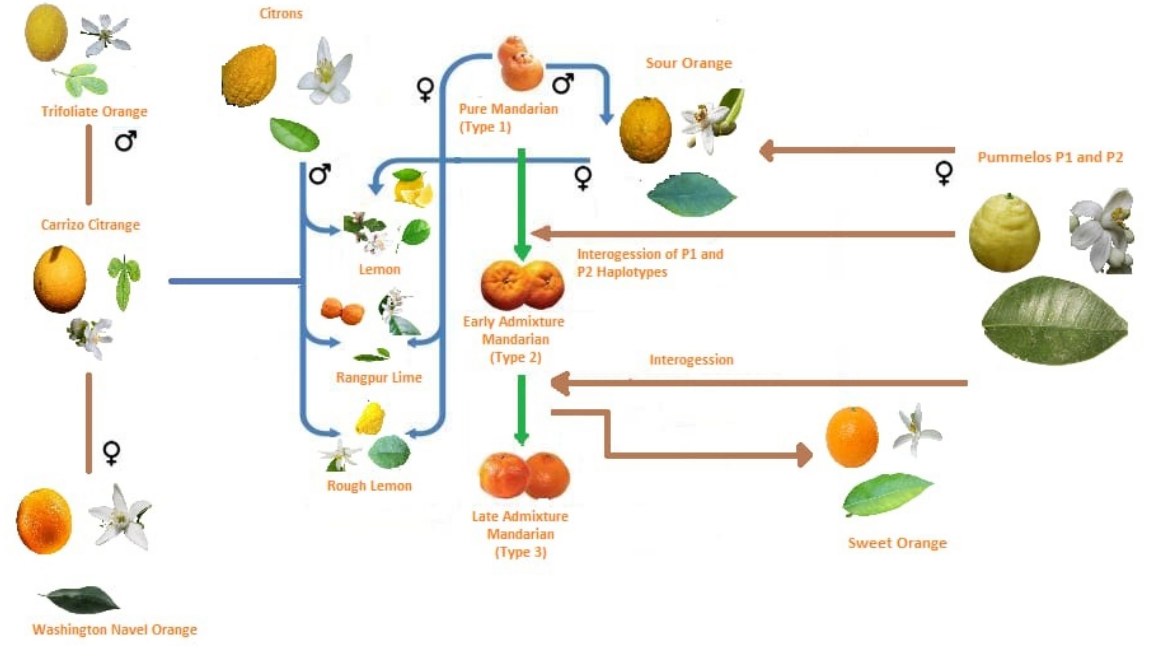

Figure 1: Genealogy of major citrus root stocks.

Growing media are the materials, other than soil, in which plants are grown. These can be non-inert materials or organic materials (De Lucia, et al., 2013). Growing media provides mechanical support to plants and acts as a reservoir for nutrients and water and a source of nutrients for plant growth (De Lucia, et al., 2013). In different parts of the world, growing media like peat moss, vermicompost, sawdust, and fine sand are used successfully, having a pivotal role in improving seed germination and enhanced seedling growth and development (Tamang and Tashi, 2019; Vishwakarma, 2013). The potting media can change canopy development patterns and functions, e.g., Photosynthesis (Feng, et al., 2016).

According to (De Lucia, et al., 2013), good potting media management is essential for producing quality fruit tree seedlings since vigorous growth is needed to face the seasonal hazards encountered on the field. According to (De Lucia, et al., 2013), a potting medium's aeration and water holding capacity is the most crucial physical factor.

Fungicides are those chemical compounds that abolish or prevent the growth of fungi or fungal spores (Yang, et al., 2011). The use of fungicides for effective control of plant diseases has become crucial in the last decades in the agriculture system. It is estimated that fungal infections cause almost $20 \%$ of yield reductions of crops worldwide (Yang, et al., 2011). Fungicides became the primary means of controlling fungi, uneconomical and more effective. The widespread use of such fungicidal compounds to control fungi in plants developments through the entrance of new pathogenic strains. Some reports revealed that few fungicides boost the defensive system of plants through the synthesis of phytoalexin and lignification of the cell wall or stimulation of enzymes involved in the synthesis of phenolic compounds (Barros, et al., 2015; Liu, et al., 2018). Numerous fungicides with different modes of action are approved and utilized. Among them, Fosetyl-Al is one of the most effective (Yang, et al., 2011). Seed germination due to Fusarium disease is improved when seeds are dressed with fungicides (Ayesha, et al., 2021). Reduced stomatal conductance, increased proline contents, and ethylene production while massive leaf abscission (92\%) were observed in the citrus rootstock, Carrizo citrange, when infected with fusarium root rot. Four fungal species, namely Fusarium oxysporum, Alternaria alternate, Aspergillus terreus, and Drechslera australiensis showed effective control when treated with 
metalaxyl mancozeb (Javaid, et al., 2006).

Similarly, Phytophthora nicotianae and Pythium disease were effectively controlled when systemic fungicides Metalaxyl and Fosetyl-Al were applied (Thomidis and Tsipouridis, 2001). Fosetyl-Al, when used as a foliar spray, gave good control of the disease P. Citropthora (Cacciola and Magnano di San Lio, 2008). Fosetyl-Al and Metalaxyl also reduced lesion area on $P$. parasitca inoculated citrons for up to 10 days after fungicide application (Cacciola and Magnano di San Lio, 2008).

The objective of the current study was to explore the best combination of fungicides and growing media to evaluate their cumulative effect on the morphological and physiochemicals parameters of the rootstock of several Citrus.

\section{MATERIALS AND METHOD}

\subsection{Collection of rootstock and materials}

Dissimilar mature fruits citrus rootstocks, i.e., Carrizo citrange (Citrus sinensis L. Osb. $\times$ Poncirus trifoliate L.), Cleopatra mandarin (Citrus reticulate Blanco), Rough lemon (Citrus jambhiri L.), and Sour orange (Citrus aurantium L.) were harvested from different fruit orchard, plant tissues of the selected rootstocks are shown in Figure 2. After harvesting the fruits, seeds were extracted by making a circumcision and twisting the two halves of the fruit in opposite directions. Extracted seeds were collected in a sieve, washed thoroughly by tap water, and then with distilled water to remove the pulp or any other mucilage attached to the seed, and then air-dried. Before sowing, the seeds were treated with Fosetyl-Aluminum and Metalaxyl, Mencozeb, along with one control treatment in which no fungicides were applied. Treated and untreated seeds were planted in pots containing peat moss, vermicompost, sawdust, and fine sand with four replications per treatment. The various treatments of fungicides that were applied are as follows F0: Control F1:Aliette (Fosetyl Aluminium 80.00\% Nonylphenol ethoxylate, branched 6.18\% Lignosulfonic acid, sodium salt, sulfomethylated 4.40\% Crystalline quartz) F2: Radiomil gold (Metalaxyl and Mancozeb (Mefenoxam 45.3\%).

(A)
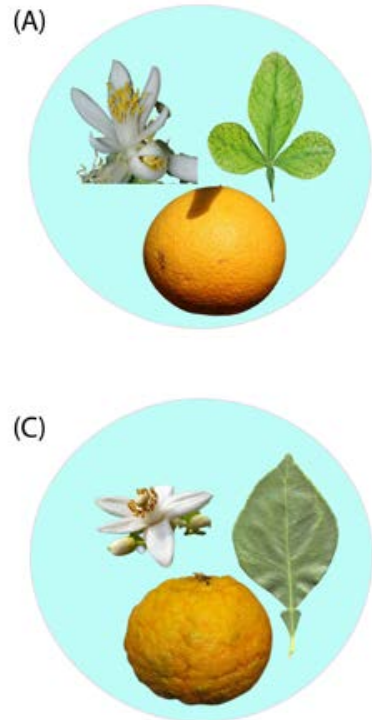
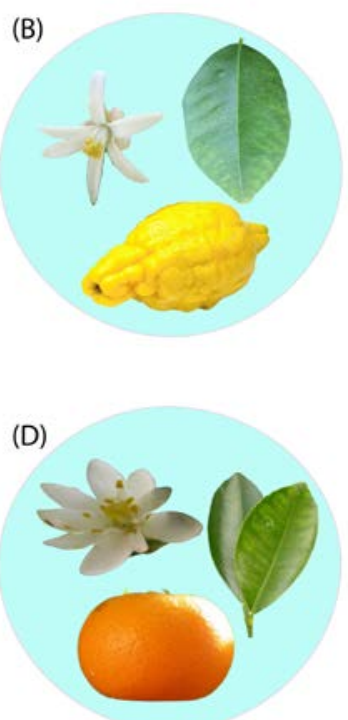

Figure 2. Fruit, Flower and leaf tissues of used root stock

(A) Carrizo citrange (Citrus sinensis L. Osb. × PoncirustrifoliateL.), (B) Rough lemon (Citrus jambhiri L.), (C) Sour orange (Citrus aurantium L.) and (D) Cleopatra mandarin (Citrus reticulateBlanco).

\subsection{Morphological parameters}

\subsubsection{Shoot and root length $(\mathrm{cm})$}

Shoot and root length were calculated using measuring tape from the ground to the ligule of most leaves of the plants of each pot, and then the average length of each plant/shoot and root was calculated. For root length, plants were uprooted from pots, and root length was recorded.

\subsubsection{Total dry and fresh biomass ( $\left(g\right.$ plant $\left.^{-1}\right)$}

Plants from each pot were harvested, and shoot fresh weight was calculated within half an hour of harvesting using a digital balance, and then the average was calculated. Whereas for dry matter, plant material was oven-dried by putting all the harvested material of shoots from each pot in an oven at $65 \pm 5^{\circ} \mathrm{C}$ for 72 hours. After drying, shoot dry weight was recorded, and then each plant's average shoot dry weight was calculated.

\subsubsection{Number of leaves plant ${ }^{-1}$}

The number of leaves was manually counted of all plants in each pot, and the mean was calculated. 


\subsubsection{Leaf area $\left(\mathrm{cm}^{2}\right)$}

Leaves were excised from plants and used to record leaf area on the leaf area meter.

\subsubsection{Physiological parameters parameters}

Stomatal conductance $\left(\mathrm{mol} / \mathrm{m}^{2} / \mathrm{s}\right)$, photosynthetic rate $\left(\mu \mathrm{mol} / \mathrm{m}^{2} / \mathrm{s}\right)$, and transpiration rate $\left(\mathrm{mmol} / \mathrm{m}^{2} / \mathrm{s}\right)$ were estimated with the help of a portable infrared gas analyzer. Observations were made on the third leaf from the top of the plant in the morning from 8:00 a.m. to 10:00 a.m that was fully expanded and youngest. The following adjustments were carried out to take observations: leaf chamber temperature varied from $25-28^{\circ} \mathrm{C}$, the surface area of leaf $6.25 \mathrm{~cm}^{2}$, ambient $\mathrm{CO}_{2}$ concentration was $371 \mu \mathrm{mol} \mathrm{mol}^{-1}$, ambient pressure into the chamber was $97.95 \mathrm{kPa}$, Photosynthetically active radiations (PAR) at the surface of leaf were maximum up to $770 \mu \mathrm{mol} \mathrm{m}^{-2} \mathrm{~s}^{-1}$, leaf chamber volume gas flow rate was $296 \mathrm{~mL} \mathrm{~min}^{-1}$ and molar gas flow rate into the chamber was $400 \mu \mathrm{mol} \mathrm{s}{ }^{-1}$.

\subsubsection{Water use efficiency $\left(\mathrm{kg} \mathrm{m}^{-3}\right)$}

The following formula used to calculate water use efficiency (WUE): WUE = Dry biomass /Total water applied

\subsubsection{Chlorophyll contents}

Chlorophyll content was determined by taking fresh leaves ( $0.5 \mathrm{~g}$ ) sample of Citrus. Leaf sample was soaked overnight in $80 \%$ acetone, then crushing and filtration and recording absorbance on a spectrophotometer. The concentration of chlorophyll was calculated following the method of (Gogoi and Basumatary, 2018).

\subsection{STATISTICAL ANALYSIS}

The obtained data were subjected to a completely randomized design (CRD) with three-factor factorial arrangements. The collected data was analyzed statistically by employing the Fisher Analysis of Variance Technique using computer software M STAT C, and treatment means were compared by applying the least significance difference (LSD) test at a $5 \%$ probability level.

\section{RESULT AND DISCUSSION \\ 3.1. Morphological parameters \\ 3.1.1. Shoot Length (cm)}

The highest shoot length $(11.97 \mathrm{~cm})$ was noted when Aliette (Fosetyl-Aluminium) was applied, followed by Radiomil gold (Metalaxyl and Mencozeb) as compared to control $(11.03 \mathrm{~cm})$. These results are similar to the reports of Türkölmez and Sibel (2017), which supports the stimulative effect of Aliette. Similarly, different growth media significantly enhanced shoot length, and a higher shoot length of $(11.37 \mathrm{~cm})$ was measured where Peat moss was used, followed by Vermicompost (Table-1). Shoot length was also affected by rootstock, and more shoot length $(11.60 \mathrm{~cm})$ was recorded when plants were grown from Cleopatra mandarin rootstock. An interactive effect was measured as maximum shoot length $(12.35 \mathrm{~cm})$ that rootstock where fungicide Aliette (Fosetyl-Aluminium) and Peat moss growth media were used with Cleopatra mandarin. It was similar when Radiomil gold (Metalaxyl and Mencozeb) and Peat moss growth media were applied. The lowest shoot length $(10.20 \mathrm{~cm})$ was measured in those plants that were grown from Carrizo citrange in sand media and where no fungicide was applied (Table-1) (Jabaji-Hare, 1985).

\subsubsection{Root Length (cm)}

Analysis of variance revealed that the effect of different fungicides, growth media, rootstock, and their interaction on the root length of Citrus was significant (Table 1). Fungicides significantly enlarged the root growth. However, more root growth $(15.01 \mathrm{~cm})$ was detected when Aliette fungicide was applied, followed by Radiomil gold compared to control $(14.67 \mathrm{~cm})$. Likewise, diverse growth media significantly boosted root length, which shows the proportional effect with the water holding capacity and greater root length $(15.11 \mathrm{~cm})$ where Peat moss was used, followed by vermicompost. In comparison, the lowest root length $(14.49 \mathrm{~cm})$ was noticed (Table-1).

Similarly, rootstock also affected the root length. More root length like $15.42 \mathrm{~cm}$ was observed when plants were grown in Cleopatra mandarin rootstock followed by rough lemon, and minimum root length $(14.44 \mathrm{~cm})$ was apparent in Sour orange rootstock (Table-1). The maximum root length $(16.40 \mathrm{~cm})$ was measured in those rootstocks where fungicide Aliette (Fosetyl- Aluminium) and Peat moss growth media were used. It was similar to Radiomil gold (Metalaxyl and Mencozeb) fungicide and Peat moss growth. The lowest root length $(13.60 \mathrm{~cm})$ was measured in those plants that were grown from Carrizo citrange in sand media and where no fungicide was applied (Table-1)(Jabaji-Hare, 1985).

\subsubsection{Total fresh biomass $(\mathrm{g})$}

The total fresh biomass reported in Table (1) received Aliette (Fosetyl- Aluminium) fungicide. Similarly, various growth 
media intentionally increased total fresh biomass, and higher total fresh biomass (5.00g) was measured in the presence of Peat moss. Likewise, rootstock also affected the total fresh biomass, and higher total fresh biomass was recognized when plants were grown from Cleopatra mandarin rootstock. An interactive effect results in maximum total fresh biomass (5.45g) in those rootstocks where fungicide Aliette (Fosetyl-Aluminium) and Peat moss growth media was used, but statistically, it was equal to that when Radiomil gold (Metalaxyl and Mencozeb) fungicide and Peat moss growth media was used which was already reported by (Atif, et al., 2016).

\subsubsection{Total dry biomass (g)}

The total dry mass presented in Table (1) indicates substantial effects of different fungicides, growth media, rootstocks, and their interaction on the total dry biomass of Citrus. It was observed that Fungicides significantly improved total dry biomass. Aliette (Fosetyl-Aluminium) produced total dry biomass (2.26g) followed by Radiomil gold (Metalaxyl and Mencozeb) as compared to control (2.21g). Analysis of variance showed that different growth media significantly enhanced total dry biomass, and total dry biomass (2.27g) was recorded where Peat moss was used. Similarly, total dry biomass was also affected by different citrus rootstocks, and higher total dry biomass (2.32g) was recorded when plants were grown from Cleopatra mandarin rootstock. Data also showed that the interactive effect of fungicides, growth media, and rootstock was significant. Maximum total dry biomass (2.45g) was noted in those rootstocks where (FosetylAluminium) fungicide and Peat moss growth media was used, which was similar to the early reports of (Thomidis and Tsipouridis, 2001) when Radiomil gold (Metalaxyl and Mencozeb) fungicide and Peat moss growth media was used. The lowest total dry biomass $(2.00 \mathrm{~g})$ was recorded in those plants grown from Carrizo citrange in sand media and where no fungicide was applied (Table-1). Results revealed that the use of fungicides significantly improved dry biomass, hence an impact on plant physiology.

\subsubsection{Number of leaves}

Plants under different fungicide treatments showed an increase in the number of leaves. However, Aliette (FosetylAluminium) treated plants produced more leaves (16.26). Similarly, several growth media significantly improved the number of leaves, and a higher number of leaves (16.39) was counted where Peat moss growth media was used (Hasan et al. 2019). Alike, rootstock also progressively affected the number of leaves. More leaves (16.68) were counted when citrus plants were grown from Cleopatra mandarin rootstock, and a minimum number of leaves (15.79) was counted in Sour orange rootstock. The interactive effect of fungicides, growth media, and rootstock revealed that the maximum number of leaves (18.00) was recorded in those rootstocks plants where fungicide Aliette (Fosetyl- Aluminium) Peat moss growth media was used (Khan, et al., 2019).

\subsubsection{Leaf area $\left(\mathrm{cm}^{2}\right)$}

The application of different fungicides improved leaf area. A higher leaf area $\left(4.99 \mathrm{~cm}^{2}\right)$ was recorded in those plants treated with Aliette (Fosetyl- Aluminium). Similarly, leaf area was also significantly improved by different growth media, and more leaf area $\left(5.15 \mathrm{~cm}^{2}\right)$ was recorded where Peat moss was used. Similarly, rootstock greatly affected the leaf area, and a greater leaf area $\left(5.10 \mathrm{~cm}^{2}\right)$ was recorded when plants were grown from Cleopatra mandarin rootstock followed by Rough lemon. Interactive effect exhibited that maximum leaf area $\left(5.43 \mathrm{~cm}^{2}\right)$ was recorded in that rootstock plants where fungicide Aliette (Fosetyl- Aluminium) and Peat moss growth media was used; though statistically, it was at similar to Radiomil gold (Metalaxyl and Mencozeb) fungicide and Peat moss growth media were used. The current search results are per reports of (Khan, et al., 2019), who reported the lowest leaf area in those plants grown from Carrizo citrange in sand media and where no fungicide was applied (Table-1)

Table 1: Morphological attributes under different rootstock and fungicides, growth media treatments.

\begin{tabular}{|c|c|c|c|c|c|c|}
\hline Treatments & No. of Leaves & $\begin{array}{c}\begin{array}{c}\text { Leaf Area } \\
\left(\mathrm{cm}^{2}\right)\end{array} \\
\end{array}$ & $\begin{array}{c}\text { Shoot Length } \\
\text { (cm) }\end{array}$ & $\begin{array}{c}\text { Root Length } \\
\text { (cm) }\end{array}$ & $\begin{array}{l}\text { Total Fresh } \\
\text { Biomass (g) }\end{array}$ & $\begin{array}{c}\text { Total Dry } \\
\text { Biomass (g) }\end{array}$ \\
\hline \multicolumn{7}{|l|}{ Fungicides } \\
\hline Control & $16.00^{\mathrm{b}}$ & $4.23^{c}$ & $11.03^{c}$ & $14.67^{c}$ & $4.06^{\mathrm{c}}$ & $2.21^{\mathrm{c}}$ \\
\hline Aliette & $16.26^{\mathrm{a}}$ & $4.99^{\mathrm{a}}$ & $11.97^{\mathrm{a}}$ & $15.01^{\mathrm{a}}$ & $4.97^{\mathrm{a}}$ & $2.26^{\mathrm{a}}$ \\
\hline Radiomil gold & $16.12^{\mathrm{b}}$ & $4.89^{\mathrm{a}}$ & $11.77^{\mathrm{b}}$ & $14.86^{\mathrm{b}}$ & $4.9^{\mathrm{a}}$ & $2.23^{\mathrm{b}}$ \\
\hline \multicolumn{7}{|l|}{ Growth Media } \\
\hline Peat moss & $4.78^{\mathrm{b}}$ & $11.37^{\mathrm{a}}$ & $15.11^{\mathrm{a}}$ & $5.00^{\mathrm{a}}$ & $2.27^{\mathrm{a}}$ & $16.39^{\mathrm{a}}$ \\
\hline Vermicompost & $5.15^{\mathrm{a}}$ & $11.25^{\mathrm{b}}$ & $14.96^{\mathrm{b}}$ & $4.94^{\mathrm{b}}$ & $2.25^{\mathrm{ab}}$ & $16.25^{\mathrm{ab}}$ \\
\hline Sawdust & $4.95^{\mathrm{b}}$ & $11.14^{\mathrm{c}}$ & $14.82^{\mathrm{c}}$ & $4.90^{\mathrm{b}}$ & $2.23^{\mathrm{b}}$ & $16.12^{\mathrm{b}}$ \\
\hline Fine sand & $4.78^{\mathrm{c}}$ & $10.89^{d}$ & $14.49^{\mathrm{d}}$ & $4.79^{\mathrm{c}}$ & $2.18^{\mathrm{c}}$ & $15.75^{\mathrm{c}}$ \\
\hline \multicolumn{7}{|l|}{ Citrus rootstocks } \\
\hline Carrizo citrange & $15.79^{c}$ & $10.85^{c}$ & $14.44^{\mathrm{c}}$ & $4.78^{c}$ & $2.17^{\mathrm{c}}$ & $4.49^{\mathrm{D}}$ \\
\hline Cleopatra mandarin & $4.77^{\mathrm{C}}$ & $11.60^{\mathrm{a}}$ & $15.42^{\mathrm{a}}$ & $5.10^{\mathrm{a}}$ & $2.32^{\mathrm{a}}$ & $16.68^{\mathrm{a}}$ \\
\hline Rough lemon (Citrus jambhiri L.) & $5.10^{\mathrm{A}}$ & $11.11^{\mathrm{b}}$ & $14.76^{\mathrm{b}}$ & $4.88^{\mathrm{b}}$ & $2.22^{\mathrm{b}}$ & $16.08^{\mathrm{b}}$ \\
\hline Sour orange (Citrus aurantium L.) & $4.88^{\mathrm{B}}$ & $11.10^{\mathrm{b}}$ & $14.75^{\mathrm{b}}$ & $4.87^{\mathrm{b}}$ & $2.22^{\mathrm{b}}$ & $15.95^{\mathrm{b}}$ \\
\hline
\end{tabular}

\section{2. $\quad$ Physiological Attributes}

3.2.1. Photosynthesis $\left(\mu \mathrm{mol} / \mathrm{m}^{2} / \mathrm{s}\right)$ \& Transpiration Rate $\left(\mu \mathrm{mol} / \mathrm{m}^{2} / \mathrm{s}\right)$ 
The use of fungicides significantly improved photosynthesis $\left(5.25 \mu \mathrm{mol} / \mathrm{m}^{2} / \mathrm{s}\right)$ and transpiration rates $\left(1.980 \mu \mathrm{mol} / \mathrm{m}^{2} / \mathrm{s}\right)$. Particularly in the plants where Aliette was used (Petit, et al., 2012; Gaitan, et al., 2005).

Photosynthesis rate was also affected by the rootstock of Citrus, and a greater photosynthesis rate (5.19 $\mu \mathrm{mol} / \mathrm{m}^{2} / \mathrm{s}$ ) was recorded when plants were grown from Cleopatra mandarin rootstock followed by Rough lemon. The least photosynthesis rate $\left(4.86 \mu \mathrm{mol} / \mathrm{m}^{2} / \mathrm{s}\right)$ was observed in Sour orange rootstock (Machado, et al., 2012).

Similarly, a higher transpiration rate was recognized when grown from Cleopatra mandarin rootstock. The interactive effect of fungicides, growth media and rootstock exhibited that maximum photosynthesis $\left(5.53 \mu \mathrm{mol} / \mathrm{m}^{2} / \mathrm{s}\right)$ and transpiration rate $\left(1.980 \mu \mathrm{mol} / \mathrm{m}^{2} / \mathrm{s}\right.$ ) was recorded in those rootstock plants where fungicide Aliette (FosetylAluminium) and Peat moss growth media was used (Table-2).

Table 2: Physio-biochemical attributes under different root stock and fungicide, growth media treatments.

\begin{tabular}{|c|c|c|c|c|c|}
\hline Treatments & $\begin{array}{c}\text { Chlorophyll } \\
\text { Contents (mg g-1 } \\
\text { FW) }\end{array}$ & $\begin{array}{c}\text { Photosynthesis } \\
\text { Rate }\left(\mu \mathrm{mol} / \mathrm{m}^{2} / \mathrm{s}\right)\end{array}$ & $\begin{array}{c}\text { Transpiration } \\
\text { Rate }\left(\mu \mathrm{mol} / \mathrm{m}^{2} / \mathrm{s}\right)\end{array}$ & $\begin{array}{c}\text { Stomatal } \\
\text { Conductance } \\
\left(\mu \mathrm{mol} / \mathrm{m}^{2} / \mathrm{s}\right)\end{array}$ & $\begin{array}{r}\text { Relative } \\
\text { water }(\%)\end{array}$ \\
\hline \multicolumn{6}{|l|}{ Fungicides } \\
\hline Control & $0.232^{\mathrm{C}}$ & $4.700^{\mathrm{C}}$ & $1.901^{\mathrm{C}}$ & $0.151^{\mathrm{B}}$ & $74.96^{\mathrm{C}}$ \\
\hline Aliette & $0.238^{\mathrm{A}}$ & $5.250^{\mathrm{A}}$ & $1.980^{\mathrm{A}}$ & $0.154^{\mathrm{A}}$ & $76.74^{\mathrm{A}}$ \\
\hline Radiomil gold & $0.236^{\mathrm{B}}$ & $5.000^{\mathrm{B}}$ & $1.968^{\mathrm{B}}$ & $0.153^{\mathrm{A}}$ & $75.99^{\mathrm{B}}$ \\
\hline \multicolumn{6}{|l|}{ Growth media } \\
\hline Peat moss & $0.236^{\mathrm{A}}$ & $5.290^{\mathrm{A}}$ & $2.001^{\mathrm{A}}$ & $0.156^{\mathrm{A}}$ & $77.29^{\mathrm{A}}$ \\
\hline Vermicompost & $0.237^{\mathrm{A}}$ & $5.040^{\mathrm{B}}$ & $1.981^{\mathrm{B}}$ & $0.154^{\mathrm{B}}$ & $76.50^{\mathrm{B}}$ \\
\hline Sawdust & $0.235^{\mathrm{B}}$ & $4.900^{\mathrm{C}}$ & $1.961^{\mathrm{C}}$ & $0.152^{\mathrm{B}}$ & $75.77^{\mathrm{C}}$ \\
\hline Fine sand & $0.230^{\mathrm{C}}$ & $4.770^{\mathrm{D}}$ & $1.961^{\mathrm{C}}$ & $0.152^{\mathrm{B}}$ & $74.05^{\mathrm{D}}$ \\
\hline \multicolumn{6}{|l|}{ Citrus root stock } \\
\hline Carrizo citrange & $0.229^{\mathrm{C}}$ & $4.860^{\mathrm{C}}$ & $1.917^{\mathrm{D}}$ & $0.149^{\mathrm{C}}$ & $73.81^{\mathrm{C}}$ \\
\hline Cleopatra mandarin & $0.245^{\mathrm{A}}$ & $5.190^{\mathrm{A}}$ & $1.911^{\mathrm{C}}$ & $0.149^{\mathrm{C}}$ & $78.84^{\mathrm{A}}$ \\
\hline Rough lemon (Citrus jambhiri L.) & $0.234^{\mathrm{B}}$ & $4.970^{\mathrm{B}}$ & $2.040^{\mathrm{A}}$ & $0.159^{\mathrm{A}}$ & $75.51^{\mathrm{B}}$ \\
\hline Sour orange (Citrus aurantium L.) & $0.234^{\mathrm{B}}$ & $4.950^{\mathrm{B}}$ & $1.955^{\mathrm{B}}$ & $0.152^{\mathrm{B}}$ & $75.45^{\mathrm{B}}$ \\
\hline
\end{tabular}

\subsubsection{Water use efficiency $\left(\mathrm{Kg} \mathrm{m}^{-3}\right)$}

Data about water use efficiency shows that water use efficiency $\left(0.238 \mathrm{Kg} \mathrm{m}^{-3}\right)$ was slightly enhanced when Aliette (Fosetyl- Aluminium) was used, followed by Radiomil gold (Metalaxyl and Mancozeb). There was low water use efficiency $\left(0.232 \mathrm{Kg} \mathrm{m}^{-3}\right)$ in control. Likewise, various growth media deliberately improved water use efficiency, and higher water use efficiency $\left(0.240 \mathrm{Kg} \mathrm{m}^{-3}\right)$ was measured where Peat moss was used. Likewise, rootstock also affected the water use efficiency, and higher water use efficiency $\left(0.245 \mathrm{Kg} \mathrm{m}^{-3}\right)$ was recognized when plants were grown from Cleopatra mandarin rootstock. It was evident from analysis of variance that interactive effect was significant, and maximum water use efficiency $\left(0.260 \mathrm{Kg} \mathrm{m}^{-3}\right)$ was recorded in those rootstocks where fungicide Aliette (FosetylAluminium) and Peat moss growth media were used, which is similar to the earlier reports of Favero, et al., (2013).

\subsubsection{Stomatal conductance $\left(\mu \mathrm{mol} / \mathrm{m}^{2} / \mathrm{s}\right)$}

Stomatal conductance is the crucial factor involved in the growth of plants. Results reported in the Table (2) showed that fungicides progressively improved stomatal conductance. Aliette (Fosetyl-Aluminium) improved more stomatal conductance $\left(0.154 \mu \mathrm{mol} / \mathrm{m}^{2} / \mathrm{s}\right)$, followed by Radiomil gold (Metalaxyl and Mencozeb) (Gaitan, et al., 2005) compared to stomatal conductance $\left(0.151 \mu \mathrm{mol} / \mathrm{m}^{2} / \mathrm{s}\right)$ in control. Data also showed that various growth media significantly enhanced stomatal conductance. More stomatal conductance $\left(0.156 \mu \mathrm{mol} / \mathrm{m}^{2} / \mathrm{s}\right)$ was recorded where Peat moss was used as a growth media followed by vermicompost (Machado, et al., 2012).

Similarly, rootstock also significantly affected the stomatal conductance, and higher stomatal conductance $(0.159$ $\mu \mathrm{mol} / \mathrm{m}^{2} / \mathrm{s}$ ) was recorded when plants were grown from Cleopatra mandarin. A maximum interactive effect on stomatal conductance $\left(0.170 \mu \mathrm{mol} / \mathrm{m}^{2} / \mathrm{s}\right)$ was noted in those rootstocks where fungicide Aliette and Peat moss growth media were used. However, it was at par with when Radiomil gold (Metalaxyl and Mencozeb) fungicide and Peat moss growth media were used. The least stomatal conductance $\left(0.140 \mu \mathrm{mol} / \mathrm{m}^{2} / \mathrm{s}\right)$ was recorded in those plants grown from Carrizo citrange in sand media and where no fungicide was applied (Table-1).

\subsubsection{Relative water contents (\%)}

It was observed that the fungicides gradually enhanced the relative water contents. However, more relative water contents (76.74\%) were observed when Aliette (Fosetyl-Aluminium) was applied, followed by Radiomilgold (Metalaxyl and Mencozeb) as compared to control (74.96\%) (Gaitan, et al., 2005). Similarly, numerous growth media significantly improved relative water contents and higher relative water contents (77.29\%) results where Peat moss growth media was used. Alike, rootstock also progressively affected the relative water contents, and more relative water contents (78.84\%) were counted when citrus plants were grown from Cleopatra mandarin rootstock. Minimum relative water contents (73.81\%) were counted in Sour orange rootstock (Machado, et al., 2012). The interactive effect revealed that maximum relative water contents $(84.00 \%)$ were recorded in those rootstocks plants where fungicide Aliette (Fosetyl- 
Aluminium) and Peat moss growth media were used. However, it was at par with when Radiomil gold (Metalaxyl and Mencozeb) fungicide and Peat moss growth media was used. The lower relative water contents (69.40\%) were recorded in those citrus plants grown from Carrizo citrange in sand media, and no fungicide was applied.

\subsection{BIOCHEMICAL PARAMETERS}

\subsubsection{Chlorophyll Contents ( $\left.\mathrm{mg} \mathrm{g}^{-1} \mathrm{FW}\right)$}

Results reported in Table (2) showed that there were significantly higher chlorophyll contents $\left(1.761 \mathrm{mg} \mathrm{g}^{-1} \mathrm{FW}\right)$ when Aliette (Fosetyl- Aluminium) was applied, followed by Radiomil gold (Metalaxyl and Mencozeb) as compared to control (1.519 $\left.\mathrm{mg} \mathrm{g}^{-1} \mathrm{FW}\right)$. Gaitan, et al., (2005) also revealed that different growth media significantly enhanced chlorophyll contents, while higher chlorophyll contents $\left(1.773 \mathrm{mg} \mathrm{g}^{-1} \mathrm{FW}\right)$ were measured when Peat moss was used, followed by vermicompost, while lowest chlorophyll contents $\left(1.699 \mathrm{mgg}^{-1} \mathrm{FW}\right)$ were observed where Fine sand was used (Table-2). Alike, rootstock also affected the chlorophyll contents, and more chlorophyll contents (1.809 $\left.\mathrm{mgg}^{-1} \mathrm{FW}\right)$ were recorded when plants were grown from Cleopatra mandarin rootstock followed by Rough lemon. Minimum chlorophyll contents (1.693 $\mathrm{mgg}^{-1} \mathrm{FW}$ ) were observed in Sour orange rootstock (Table 2). Maximum chlorophyll contents $\left(1.925 \mathrm{mgg}^{-1} \mathrm{FW}\right)$ were measured in that rootstock where fungicide Aliette and Peat moss growth media were used; however, statistically, it was at par with Radiomil gold (Metalaxyl and Mencozeb) fungicide and Peat moss growth media. The lowest chlorophyll contents $\left(1.590 \mathrm{mgg}^{-1} \mathrm{FW}\right)$ were measured in those plants grown from Carrizo citrange in sand media and where no fungicide was applied (Graf, et al., 2013). Chlorophyll is an essential factor of light signaling transcription that plays an essential role in regulating plant development and responses. An increase in chlorophyll concentration is directly related to the morphological parameters of the plants(Table-1)

\section{CONCLUSION}

After analysis of the results, it was revealed that all fungicides, media, and rootstocks influence Citrus's morphological and physicochemical parameters. It was recognized that the best performance was observed in the combination where Aliette is used with peat moss and Cleopatra mandarin. And the combination of Radiomil Gold, peat moss with the same rootstock is slightly lagging behind the first combination. A poor growth rate was observed where Sand as a growth media and Carrizo citrange as a rootstock were used. This study reveals that healthy and vigorous rootstocks can be attained by the proper selection and combination of fungicides, growth media, and rootstocks, ensuring the best quality orchards with maximum survival rate and high yields.

\section{Acknowledgment}

The authors are highly grateful to the Faculty of the Agriculture University of Sargodha Pakistan and Anhui Agricultural University, China, for supporting this work and providing research facilities.

\section{Conflict of Interest}

No conflict of interest among the authors

\section{REFERENCES}

Albacete, A., Martínez-Andújar, C., Martínez-Pérez, A., Thompson, A. J., Dodd, I. C., \& Pérez-Alfocea, F. (2015). Unravelling rootstock $\times$ scion interactions to improve food security. Journal of experimental botany, 66(8), 2211-2226.

Atif, M. J., Jellani, G., Malik, M. H. A., Saleem, N., Ullah, H., Khan, M. Z., \& Ikram, S. (2016). Different growth media effect the germination and growth of tomato seedlings. Science, Technology and Development, 35(3), 123-127.

Ayesha, M. S., Suryanarayanan, T. S., Nataraja, K. N., Prasad, S. R., \& Shaanker, R. U. (2021). Seed Treatment With Systemic Fungicides: Time for Review. Frontiers in Plant Science, 1581.

Barros, J., Serk, H., Granlund, I., \& Pesquet, E. (2015). The cell biology of lignification in higher plants. Annals of botany, 115(7), 1053-1074.

Cacciola, S. O., \& di San Lio, G. M. (2008). Management of citrus diseases caused by Phytophthora spp. In Integrated management of diseases caused by fungi, phytoplasma and bacteria (pp. 61-84). Springer, Dordrecht.

Cirmi, S., Maugeri, A., Ferlazzo, N., Gangemi, S., Calapai, G., Schumacher, U., \& Navarra, M. (2017). Anticancer potential of citrus juices and their extracts: a systematic review of both preclinical and clinical studies. Frontiers in Pharmacology, 8, 420. 
De Lucia, B., Cristiano, G., Vecchietti, L., Rea, E., \& Russo, G. (2013). Nursery growing media: agronomic and environmental quality assessment of sewage sludge-based compost. Applied and Environmental Soil Science, 2013.

Fadli, A., El Aymani, I., Chetto, O., Boudoudou, D., Talha, A. B. R., \& Benyahia, H. (2015). Screening of six citrus rootstocks for salt tolerance at emergence and early seedling stage. International Journal of Recent Scientific Research, 6(12), 7672-7678.

Fallahi, E., Colt, W. M., Fallahi, B., \& Chun, I. J. (2002). The Importance of Apple Rootstocks on Tree Growth, Yield, Fruit Quality, Leaf Nutrition, and Photosynthesis with an Emphasis onFuji'. HortTechnology, 12(1), 38-44.

Feng, G., Luo, H., Zhang, Y., Gou, L., Yao, Y., Lin, Y., \& Zhang, W. (2016). Relationship between plant canopy characteristics and photosynthetic productivity in diverse cultivars of cotton (Gossypium hirsutum L.). The Crop Journal, 4(6), 499-508.

Gamboa Gaitan, M. A., Wen, S., Fetcher, N., \& Bayman, P. (2005). Effects of fungicides on endophytic fungi and photosynthesis in seedlings of a tropical tree, Guarea guidonia (Meliaceae). Acta biológica colombiana, 10(2), 41-48.

Gogoi, M., \& Basumatary, M. (2018). Estimation of the chlorophyll concentration in seven Citrus species of Kokrajhar district, BTAD, Assam, India. Tropical Plant Research, 5(1), 83-87.

Graf-Grachet, N. (2015). Effect of foliar fungicides on relative chlorophyll content, green leaf area, yield and test weight of winter wheat (Doctoral dissertation, Oklahoma State University).

Hasan, A. E., Bhiah, K. M., \& Al-Zurfy, M. T. (2014). The impact of peat moss and sheep manure compost extracts on marigold (Calendula officinalis L.) growth and flowering. Journal of Organic Systems, 9(2), 56-62.

Hussain, H. A., Hussain, S., Khaliq, A., Ashraf, U., Anjum, S. A., Men, S., \& Wang, L. (2018). Chilling and drought stresses in crop plants: implications, cross talk, and potential management opportunities. Frontiers in plant science, 9, 393.

Jabaji-Hare, S. H. (1985). Effects of fosetyl-Al on root exudation and on composition of extracts of mycorrhizal and nonmycorrhizal leek roots. Canadian Journal of Plant Pathology, 7(2), 118-126.

Arshad, J., Asma, A., Naureen, A., Hanif, M., \& Farooq, M. A. (2006). Efficacy of some fungicides against seed-borne mycoflora of wheat. Mycopath, 4(1), 45-49.

Khan, A. A., Bibi, H., Ali, Z., Sharif, M., Shah, S. A., Ibadullah, H., ... \& Ali, S. (2017). Effect of compost and inorganic fertilizers on yield and quality of tomato. Academia Journal of Agricultural Research, 5(10), 287-293.

Klimek-Szczykutowicz, M., Szopa, A., \& Ekiert, H. (2020). Citrus limon (Lemon) phenomenon—a review of the chemistry, pharmacological properties, applications in the modern pharmaceutical, food, and cosmetics industries, and biotechnological studies. Plants, 9(1), 119.

Liu, Q., Luo, L., \& Zheng, L. (2018). Lignins: biosynthesis and biological functions in plants. International journal of molecular sciences, 19(2), 335.

Machado, D. F. S. P., Ribeiro, R. V., Silveira, J. A. G. D., Magalhães Filho, J. R., \& Machado, E. C. (2013). Rootstocks induce contrasting photosynthetic responses of orange plants to low night temperature without affecting the antioxidant metabolism. Theoretical and Experimental Plant Physiology, 25, 26-35.

Petit, A. N., Fontaine, F., Vatsa, P., Clément, C., \& Vaillant-Gaveau, N. (2012). Fungicide impacts on photosynthesis in crop plants. Photosynthesis research, 111(3), 315-326.

Riaz, A. T. I. F., Younis, A., Taj, A. R., Karim, A., Tariq, U., Munir, S., \& Riaz, S. I. T. W. A. T. (2013). Effect of drought stress on growth and flowering of marigold (Tagetes erecta L.). Pakistan Journal of Botany, 45(S1), 123-131. 
Ribeiro, R. V., Espinoza-Núñez, E., Junior, J. P., Mourão Filho, F. A., \& Machado, E. C. (2014). Citrus rootstocks for improving the horticultural performance and physiological responses under constraining environments. In Improvement of crops in the era of climatic changes (pp. 1-37). Springer, New York, NY.

Tamang, B. B., \& Tashi, S. (2019). Germination and Growth of Citrus: Trifoliate Orange (Poncirus trifoliata (L.) in Different Organic Substrates. Journal of Agricultural Studies, 7(3), 213-226.

Tsipouridis, K., \& Thomidis, T. (2001). Effectiveness of metalaxyl, fosetyl-Al, dimethomorph, and cymoxanil against Phytophthora cactorum and P. citrophthora of peach tree. Effectiveness of metalaxyl, fosetyl-Al, dimethomorph, and cymoxanil against Phytophthora cactorum and P. citrophthora of peach tree, 1000-1007.

Türkölmez, Ş., \& DerviŞ, S. (2017). Activity of metalaxyl-m+ mancozeb, fosetyl-al, and phosphorous acid against Phytophthora crown and root rot of apricot and cherry caused by Phytophthora palmivora. Plant Protection Science, 53(4), 216-225.

Vishwakarma, D. (2013). Effect of Growing Media and GA3 on Seed Germination, Growth and Survival of Acid Lime (Citrus aurantifolia Swingle) var. Kagzi (Doctoral dissertation, JNKVV).

Wu, G. A., Terol, J., Ibanez, V., López-García, A., Pérez-Román, E., Borredá, C., ... \& Talon, M. (2018). Genomics of the origin and evolution of Citrus. Nature, 554(7692), 311-316.

Yang, C., Hamel, C., Vujanovic, V., \& Gan, Y. (2011). Fungicide: modes of action and possible impact on nontarget microorganisms. International Scholarly Research Notices, 2011.

Zaher-Ara, T., Boroomand, N., \& Sadat-Hosseini, M. (2016). Physiological and morphological response to drought stress in seedlings of ten Citrus. Trees, 30(3), 985-993. 